DOI https://doi.org/10.30525/978-9934-26-180-0-47

\title{
ПРОЄКТНА ДІЯЛЬНІСТЬ НА ЗАНЯТТЯХ ІНОЗЕМНОЇ МОВИ ЯК ЗАСІБ ПІДВИЩЕННЯ ЕСТЕТИЧНОЇ КУЛЬТУРИ СТУДЕНТІВ НЕМОВНИХ СПЕЦІАЛЬНОСТЕЙ ВНЗ
}

\author{
Боклах Д. Ю. \\ викладач кафедри іноземних мов і професійної комунікаиії \\ Східноукрайнський наиіональний університет \\ імені Володимира Даля \\ м. Сєвєродонецьк, Луганська область, Україна
}

Навчання іноземній комунікації з використанням проєктної технології $€$ цілком конкурентною альтернативою традиційному вивченню мови. Ця конкурентність значно посилюється, коли ми говоримо про залучення до проєктів інформаційних джерел, які мають не лише лінгвокраїнознавчий зміст, а вміщують комплекс художньої сфери, яка, завдяки своїй символічній природі, покликана удосконалювати в студентів відчуття прекрасного у мистецтві, формувати естетичні смаки і цінності культури, голоси якої «лунають у ночі нігілізму та духовної всеїдності» [6, с. 3]. Актуальність проєктної методики у підвищенні естетичної культури $\epsilon$ беззаперечною, оскільки сучасні масові зразки моралі стирають межі розуміння глибини естетичної парадигми людського поступу.

Нинішній стан вивчення іноземної мови у ВНЗ України зведено до використання мови у науковій, діловій, побутовій сферах, натомість помітною $\epsilon$ недостатня увага до формування естетичної культури в шкільній та університетській іншомовній підготовці. Погодимося зі слушною думкою Л. Цвяк про те, що на сьогодні виховний потенціал дисципліни «Іноземна мова» використовується одноманітно, адже «процес викладання іноземної мови орієнтований переважно на засвоєння іншомовної лексики» [7, с. 189]. Естетизм мовної матерії, іiі зображальновиражальний потенціал оприявлено в університетських курсах іноземної мови лише для студентів гуманітарних спеціальностей.

Упровадження проєктних технологій у навчанні студентів іноземної мови розглянуто в працях І. Бондар, О. Гладкої, З. Заврумова, О. Коваль, Р. Кульбакової, І. Свинторжицької та ін. Теоретичні аспекти використання лінгвальних засобів іноземної мови 3 метою формування естетичної культури, естетичного виховання студентів в освітньому процесі ВНЗ досліджували Л. Абрамова, О. Ковальов, В. Карташова, Н. Оксень, Л. Черниш та ін. Варто наголосити, що методичні аспекти проєктної 178 
діяльності на заняттях іноземної мови у ВНЗ на засадах розвитку естетичної культури здобувачів освіти немовних спеціальностей $\epsilon$ недостатньо дослідженими, тому складають наукову зацікавленість.

Проєктна методика в опануванні іноземної мови відіграє синхронізуючу роль між активною творчістю, розвитком комунікації, умінням оригінально презентувати матеріал.

Естетика - наука про споглядальне, творче ставлення людини до дійсності, що вивчає специфічний досвід ії освоєння, у процесі якого людина відчуває, переживає духовно-чуттєву ейфорію, захоплення, радість, блаженство [4, с. 456]. Отже, естетичне виховання має формувати, удосконалювати чуттєве, гостро індивідуальне осягнення мистецької дійсності. Важливим у контексті естетичної культури є поняття «естетичної свідомості», яка охоплює «естетичне ставлення людини до дійсності, яке реалізується через співвідношення прекрасного i потворного» [1, с. 274].

Н. Оксень зауважує, що метою навчання іноземної мови на основі проєктної методики $є$ формування комунікативної компетенції студентів у сукупності лінгвістичного, соціокультурного, когнітивного та особистісного компонентів [5]. У цей перелік цілком органічно додамо культурологічний та естетичний компоненти, останній з яких варіює власне опанування іноземної мови та розуміння художніх особливостей мистецьких творів

Визначимо, що ключовими цілями використання проєктів у процесі вивчення іноземної мови задля підвищення естетичної культури є: 1) уміння студента використовувати раніше набутий досвід розуміння «прекрасного» у мистецтві; 2) особистісний інтерес до предмета відтворення, обраного за власним бажанням; 3) рівень володіння іноземною мовою в контексті розуміння мистецького твору, його емотивної палітри для удосконалення своїх смаків.

I. Дерюгіна виокремлює компоненти естетичного виховання студентів немовних спеціальностей у процесі вивчення іноземної мови: інтонаційно-образний, емоційно-образний, мотиваційний, створення ситуацій, спрямованих на підвищення рівня естетичного розвитку [3, с. 8]. Зважаючи на це, підвищення естетичної культури студентів засобами іноземної мови пропонуємо з урахуванням таких компонентів: літератури, живопису, музики, архітектури, театру, кіно. Цей перелік пояснюємо винятковими зображально-виражальними засобами відтворення аури «прекрасного», але водночас названі складники реалізують тісну міжмистецьку взаємодію з іншими видами мистецтв (скульптура, графіка, хореографія тощо), утворюючи інтермедіальну сферу естетики. Тому, 
готуючи проєкт, необхідно залучати різні канали сприйняття мовної інформації, аби унаочнити матеріал.

Студентам нефілологічних спеціальностей на заняттях іноземної мови (зокрема англійської) пропонуємо ситуативну тематику проєктів:

- The games of Feelings (поезії В. Шекспіра, Е. Дікінсон);

- The Riot of Feelings (фільми «Титанік», «Джейн Ейр»);

- The City through the Teenager's Eyes (романи «Ловець у житі», «Великий Гетсбі»);

- The Urban Style Pictures;

- Virtual Journey through an English Medieval City;

- Travel by the Waves with J. G. Byron;

- The Beauty of the Soul and Art (роман і фільм «Портрет Доріана Грея»);

- The Meaning of Life or Simply Life? (повість «Старий і море»);

- The Cosmic Soul of the People and Transcendental Nature of the World (твори В. Вітмена);

- World Painting and English Artists of the 18th century;

- Landscapes of England in the Paintings of John Constable;

- We and the Human Qualities of Robert Burns' Poetry та ін.

Досить продуктивним у проєктній діяльності є елементи драматизму. На думку Н. Барвіної, драматизація передбачає комплексний підхід, вибудуваний на втіленні конфлікту в художніх образах, що сприяє активізації вербальних і невербальних комунікативних навичок в процесі творчого оволодіння знаннями художньо-естетичного матеріалу [2, с. 2829]. Особливу роль відіграють вербальні і невербальні компоненти мови, адже вони занурюють у контекст драматичного твору, пов'язаного 3 розумінням ідейно-художньої специфіки іншомовного тексту.

Завдання проєкту - в процесі вивчення іноземної мови залучити студентів до активної співтворчості, синтезу мистецьких творів, у яких вони поринають у захоплюючий світ. I. Дерюгіна наголошує на методичному потенціалі таких аспектів викладання іноземної мови на засадах естетичного спрямування: інтонаційно-образному, лінгвокультурологічному, використанні програм поліхудожнього розвитку, педагогічної підтримки студентської творчості [3, с. 8]. 3-поміж названого акцентуємо увагу на методичному супроводі викладача проєктної діяльності студентів, а саме - підготовці і відбору інформації, іiї структурному поєднані, мовному оформленні, способах відтворення тощо.

Отже, проєктна діяльність студентів немовних спеціальностей ВНЗ спрямована на їхню культурну компетентність, розвиток продуктивної співтворчості, особистісної мотивації, що дозволяє розвивати естетичні 
смаки, виражати своє мистецьке розуміння і почуття іноземною мовою. Естетичне спрямування проєкту має визначати орієнтованість на мистецький результат, співвіднесеність 3 відтворюваною епохою, міждисциплінарність, особисті враження студентів. Проєктна технологія реалізує суть розвивального, студентоцентричного навчання, тому може бути використана на будь-якому занятті.

\section{Література:}

1. Андрущенко В. Михальченко М. Сучасна соціальна філософія: Курс лекцій. Київ: Генеза, 1996. 370 с.

2. Барвіна Н.О. Можливості театральної педагогіки в художньоестетичному вихованні студентів в умовах театру-студії Духовність особистості: методологія, теорія і практика. 2018. №1. С. 22-33.

3. Дерюгина И. В. Эстетическое воспитание студентов неязыковых вузов средствами иностранного (английского) языка: автореф. дисс. канд.пед. наук : 13.00.02. Москва, 2008. 244 с.

4. Новая философская энциклопедия: в 4 т. / В. С. Степин, А. А. Гусейнов, Г. Ю. Семигин, А. П. Огурцов. Москва: Мысль, 2010. T. $4.736 \mathrm{c}$.

5. Оксень Н. А. Шляхи реалізації завдань естетичного виховання студентів засобами іноземної мови Наукові праиі Донецького національного технічного університету. Серія: Педагогіка, психологія $і$ соиіологія. 2009. Випуск 6. URL: http://ea.donntu.edu.ua:8080/jspui/ handle/123456789/11150

6. Суханцева В. К. Метафизика культуры. Киев: Факт, 2006. 368 с.

7. Цвяк Л. В. Педагогічні умови естетичного виховання курсантів у процесі вивчення іноземної мови Науковий вісник Ужгородського національного університету: Серія: Педагогіка. Соціальна робота. 2012. Вип. 24. С. 188-191. 